\title{
Kajian Emisi Partikulat Dan Gas Dari Suatu Pertambangan Nikel Di Halmahera Tengah
}

\author{
Agung Ghani Kramawijaya \\ Program Studi Teknik Lingkungan, Institut Teknologi Nasional Bandung \\ agung.ghani@itenas.ac.id
}

\begin{abstract}
ABSTRAK
Nikel merupakan jenis logam yang sangat penting untuk infrastruktur modern, sehingga pencarian deposit nikel terus dilakukan untuk memenuhi kebutuhan nikel di dunia. Indonesia merupakan negara dengan deposit nikel yang sangat besar, yaitu 16.200 kt nikel. Salah satu lokasi di Indonesia yang memiliki kandungan nikel adalah Halmahera Tengah. Bijih lateric yang mengandung nikel diangkat dari dalam bumi untuk diolah dan dihasilkan bijih nikel. Keberadaan pertambangan nikel memiliki berbagai dampak negatif terhadap lingkungan, salah satunya adalah penurunan kualitas udara akibat peningkatan konsentrasi pencemar udara. Berbagai jenis pencemar diemisikan dari kegiatan pertambangan, diantaranya adalah partikulat, $\mathrm{NO}$, $\mathrm{SO}_{2}, \mathrm{SO}_{3}+\mathrm{H}_{2} \mathrm{SO}_{4}$, debu nikel, dan $\mathrm{H}_{2} \mathrm{~S}$. Tingkat konstribusi pertambangan nikel terhadap pencemaran udara dapat dilihat dengan menghitung laju emisi dari kegiatan operasional pertambangan. Laju emisi dari pertambangan nikel dapat diperoleh melalui invetarisasi emisi. Kegiatan dan proses di pertambangan nikel yang berpotensi menjadi sumber emisi diidentifikasi terlebih dahulu dalam tahap pertama inventarisasi emisi. Selanjutnya, perhitungan emisi dilakukan berdasarkan ketersediaan data yang diperoleh. Faktor emisi yang dipilih dalam perhitungan emisi mempertimbangkan ketersediaan data. Emisi dihitung dengan mengalikan faktor emisi dengan data aktifitas. Berdasarkan hasil inventarisasi emisi, diketahui bahwa pencemar yang paling banyak dihasilkan oleh pertambangan nikel adalah partikulat dengan jumlah 35.173,96 ton. Sumber utama partikulat adalah pertambangan bijih dengan kontribusi sebesar 83\%. Sementara itu, gas pencemar yang paling banyak diemisikan dari pertambangan nikel adalah $\mathrm{SO}_{2}$ dengan jumlah 8.392,61 ton. Sumber utama gas $\mathrm{SO}_{2}$ adalah pabrik asam dengan kontribusi sebesar $72 \%$.
\end{abstract}

Kata Kunci: inventarisasi emisi, pertambangan nikel, emisi gas, emisi partikulat

\begin{abstract}
Nickel is one kind of a very important metal used for modern infrastructure, so the exploration of nickel deposits conducted continuesly to meet the needs of nickel around the world. Indonesia is a country with very large nickel deposits, ie 16,200 kt of nickel. One of the locations in Indonesia which has a nickel content is Central Halmahera. Lateric bijih containing nickel was mined from the earth to be processed and produced nickel bijih. Nickel mining has many negative environment impacts, one of them is air quality decrease due to increased concentration of air pollutants. Various types of pollutants are emitted from mining activities, such as particulates, $\mathrm{NOx}, \mathrm{SO}_{2}, \mathrm{SO}_{3}+\mathrm{H}_{2} \mathrm{SO}_{4}$, nickel dust, and $\mathrm{H}_{2} \mathrm{~S}$. The contribution of air pollution from nickel mining can be found by estimate the emissions rate from mining operations. Emission rate of the nickel mining can be obtained through emission inventory. The emission source of the activities and processes in nickel mining has to be identified first in the first stages of emission inventory. Furthermore, the estimation of emissions is conducted based on the availability of obtained data. The chosen emission factor in the estimation of emissions considers the availability of data. Emissions are calculated by multiplying the emission factor with activity data. Based on the result of emission inventory, the most pollutants emitted from nickel mining is particulate. Total amount of particulate emission is 35,173.96 tonnes. Main source of particulate is ore mining with contribution of $83 \%$. Meanwhile, the most emitted gas from nickel mining is $\mathrm{SO}_{2}$ with the amount of 8,392.61 tons.Main source of $\mathrm{SO}_{2}$ is acid plant with contribution of $72 \%$.
\end{abstract}

Keywords: emission inventory, nickel mining, gas emission, particulate emission 


\section{PENDAHULUAN}

Nikel merupakan logam yang penting dalam teknologi dan infrastruktur modern, dengan penggunaan terbanyak dalam stainless steel ( $\sim 58 \%)$, logam campuran nikel ( 14\%), logam campuran baja ( 9\%), electroplating $(\sim 9 \%)$, dan baterai isi ulang $(\sim 5 \%)$. Pada umumnya nikel berasal dari dua jenis bijih, yaitu sulfida dan lateric. Bijih sulfida berasal dari proses vulkanik atau hidrotermal dan biasanya terkandung pula tembaga $(\mathrm{Cu})$ dan/atau kobalt $(\mathrm{Co})$, dan tak jarang logam berharga seperti emas $(\mathrm{Au})$ atau platina $(\mathrm{Pt})$, palladium $(\mathrm{Pd})$, dan rhodium $(\mathrm{Rh})$ [1]. Sedangkan bijih lateric terbentuk dekat permukaan tanah dikarenakan pelapukan ekstensif, dan sering terjadi di lokasi tropis dekat ekuator [2].

Indonesia merupakan negara yang memiliki kandungan deposit nikel yang sangat banyak, yaitu $16.200 \mathrm{kt}$ nikel [3] dengan bijih bertipe lateric. Indonesia telah menjadi pemasok utama nikel di dunia, yaitu mendekati angka $190 \mathrm{kt}$ nikel per tahun. Sebagian besar diproduksi oleh PT. Inco (73 kt/tahun) dan PT. Antam (26 kt/tahun) [4]. Salah satu lokasi di Indonesia dengan cadangan nikel yang besar adalah Halmahera Tengah. Lokasi pertambangan pada penelitian ini adalah 2 lokasi pertambangan utama di Halmahera Tengah yaitu Bukit limber (Santa monica) dan Coastal. Bijih yang terindikasi di lokasi ini adalah bijih lateric sebanyak 341 juta ton dengan kandungan nikel rata-rata sebesar 1,49\%. Bukit limber adalah lokasi yang terindikasi mengandung bijih terbesar, yaitu 115 juta ton.

Pada prinsipnya, kegiatan pertambangan nikel dapat menyebabkan penurunan kualitas lingkungan, salah satunya adalah peningkatan partikulat dan gas di udara. Partikulat dan gas diemisikan dari seluruh kegiatan di pertambangan nikel. Oleh karena itu perlu adanya kajian terhadap partikulat dan gas untuk menetapkan kebijakan pengendalian pencemaran udara di pertambangan nikel.

\section{METODOLOGI}

Dalam penelitian ini, kajian emisi dari pertambangan nikel dilakukan melalui beberapa tahap yang dapat dilihat pada Gambar 1.

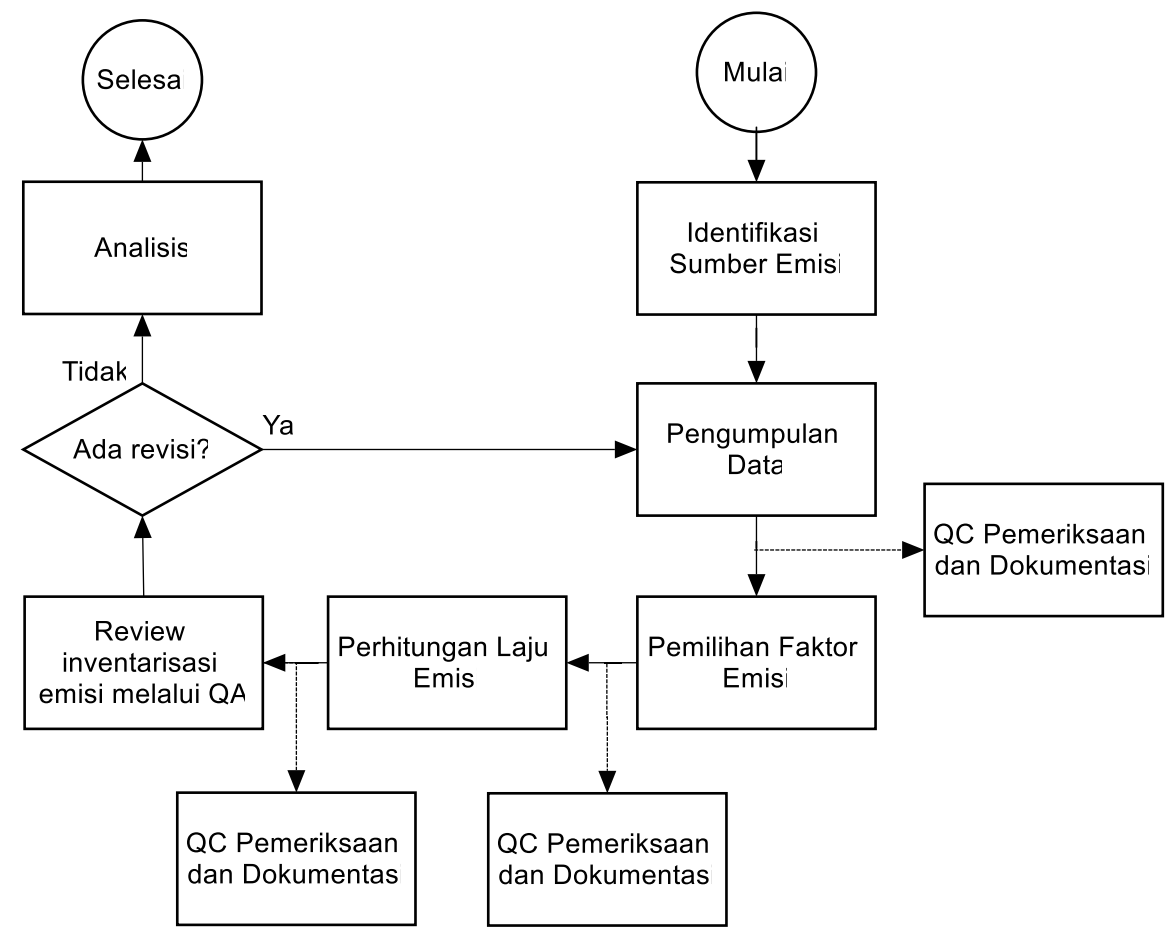

Gambar 1. Diagram Alir Metodologi Penelitian

Rekayasa Hijau - 167 


\section{Identifikasi Sumber Emisi}

Dalam proses melakukan estimasi terhadap jumlah emisi dari seluruh kegiatan pertambangan nikel, hal pertama yang harus dilakukan adalah mengidentifikasi sumber yang berpotensi menghasilkan emisi dari setiap kegiatan pertambangan. Sebagian besar sumber emisi berhubungan langsung dengan pertambangan nikel, transportasi, dan fasilitas lainnya yang mendukung kegiatan proses produksi.

\section{Pengumpulan Data}

Inventori emisi gas dan partikulat dari kegiatan pertambangan nikel dapat dilakukan apabila beberapa data sekunder telah diperoleh. Dari data yang diperoleh tersebut, perhitungan tingkat emisi dilakukan untuk mengetahui besarnya emisi, baik gas maupun partikulat, yang dihasilkan dari pertambangan nikel. Data-data yang dibutuhkan meliputi:

1. Jenis kegiatan operasional yang dilakukan di area pertambangan

2. Peta daerah operasional pertambangan

3. Data faktor emisi dari setiap kegiatan yang berpotensi menghasilkan emisi

4. Jumlah material yang ditangani dan diproses di area pertambangan nikel. Jenis material meliputi bijih, overburden $(\mathrm{OB})$, dan batu kapur.

5. Jumlah, jenis dan spersifikasi alat berat yang digunakan pada kegiatan

6. Luas area stockpile dan berat jenis bijih

\section{Quality Check (QC) Pemeriksaan dan Dokumentasi}

Selama proses inventarisasi emisi selalu dilakukan verifikasi, dokumentasi, dan prosedur pemeriksaan untuk meminimalisir kesalahan dan inkonsistensi dalam perhitungan inventarisasi. Selain itu, prosedur QC juga dilakukan untuk pendokumentasian sumber data, metode, dan asumsi yang digunakan dalam estimasi emisi.

\section{Pemilihan Faktor Emisi}

Pada penelitian ini, faktor emisi digunakan untuk menghitung laju emisi di pertambangan nikel. Faktor emisi dapat digunakan untuk melakukan estimasi laju emisi dari berbagai sumber. Faktor emisi menghubungkan jumlah substansi yang diemisikan dari berbagai sumber terhadap aktivitas yang berhubungan dengan sumber [5]. Aktivitas yang dimaksud mencakup jarak tempuh, kuantitas bahan yang ditangani, atau durasi aktivitas. Faktor emisi yang digunakan dalam penelitian ini diambil dari berbagai macam sumber, yaitu USEPA AP-42 dan Mojave Desert Air Quality Management District. Hal ini dikarenakan Indonesia belum memiliki faktor emisi spesifik negara Indonesia. Pemilihan faktor emisi didasarkan pada jenis kegiatan dan data aktifitas pertambangan yang tersedia.

\section{Perhitungan Laju Emisi}

Berdasarkan data-data yang diperoleh, perhitungan tingkat emisi dilakukan untuk mengetahui besarnya emisi, baik gas maupun partikulat, yang dihasilkan dari pertambangan nikel. Secara umum model emisi dapat dinyatakan pada Persamaan 1 [6]:

$\mathrm{E}=\mathrm{A} \times \mathrm{EF} \times(1-E R / 100)$

Dimana:

$\mathrm{E} \quad=$ Laju emisi (ton/tahun)

A $\quad=$ Laju aktivitas (aktivitas/tahun)

$\mathrm{EF} \quad=$ Faktor emisi (tones/aktivitas)

ER $\quad=$ Efisiensi penurunan emisi $(\%)$

\section{Quality Assurance (QA)}

Pemeriksaan QA terakhir dilakukan untuk memastikan bahwa tidak ada kesalahan dan inkonsistensi di dalam perhitungan. Jika saat pemeriksaan ditemukan kesalahan dan/atau inkonsistensi, maka tahap inventarisasi emisi perlu dimulai kembali dari pengumpulan data yang sesuai dengan kebutuhan revisi. 


\section{Analisis}

Hasil perhitungan emisi dari proses inventarisasi emisi dipresentasikan secara kualitatif dan kuantitatif dalam bentuk deskriptif, tabulasi, grafik, dan tabel yang dapat menggambarkan dan menyampaikan jumlah emisi yang dihasilkan dari kegiatan pertambangan nikel.

\section{HASIL DAN PEMBAHASAN}

Kajian terhadap emisi partikulat dan gas pertambangan nikel dilakukan berdasarkan beban emisi dari tambang nikel. Perhitungan laju emisi dari kegiatan operasional pertambangan nikel terdiri dari beberapa sumber, meliputi pertambangan bijih, pengolahan bijih, penggalian dan pengolahan batu kapur, fasilitas-fasilitas pendukung yang menunjang poduksi nikel, dan transportasi. Hasil perhitungan yang akan dibahas adalah beban emisi pada operasi tahun 2012 sebagai gambaran awal tingkat emisi pertambangan nikel saat kegiatan operasional baru dimulai.

\section{Sumber Emisi}

Dalam proses melakukan estimasi terhadap jumlah emisi dari seluruh kegiatan pertambangan nikel, hal pertama yang harus dilakukan adalah mengidentifikasi sumber yang berpotensi menghasilkan emisi dari setiap kegiatan pertambangan nikel. Untuk mengetahui sumber emisi di pertambangan nikel, maka kita harus mengetahui seluruh proses yang terjadi di pertambangan nikel, dari awal sampai akhir. Hasil identifikasi dapat dilihat pada Tabel 1. Berdasarkan hasil identifikasi diketahui bahwa pencemar yang diemisikan dari kegiatan pertambangan nikel meliputi partikulat yang umumnya dinyatakan dalam TSP (Total Suspended Particulate), NOx, $\mathrm{SO}_{2}, \mathrm{H}_{2} \mathrm{~S}$, dan $\mathrm{SO}_{3}+\mathrm{H}_{2} \mathrm{SO}_{4}$.

Tabel 1. Sumber-sumber emisi di pertambangan nikel

\begin{tabular}{|c|c|c|c|}
\hline No. & Sumber Emisi & Deskripsi & $\begin{array}{l}\text { Parameter } \\
\text { Emisi }\end{array}$ \\
\hline \multicolumn{4}{|c|}{ Emisi Dari Area Penambangan } \\
\hline 1 & $\begin{array}{l}\text { Pengupasan tanah } \\
\text { puncuk \& } \\
\text { Penyimpanan soil }\end{array}$ & $\begin{array}{l}\text { Emisi saat penggalian dengan mengunakan scraper } \\
\text { Emisi yang dihasilkan saat scraper digunakan untuk } \\
\text { proses pengangkutan ke truk }\end{array}$ & Partikulat \\
\hline \multirow[t]{2}{*}{2} & $\begin{array}{l}\text { Pengangkutan } \\
\text { overburden }\end{array}$ & $\begin{array}{l}\text { Emisi saat pengangkutan overburden menuju area } \\
\text { dumping area untuk sementara dengan } \\
\text { menggunakan truk }\end{array}$ & Partikulat \\
\hline & & $\begin{array}{l}\text { Emisi saat bongkar muat overburden dari truk saat } \\
\text { membentuk permukaan tanah area tambang }\end{array}$ & Partikulat \\
\hline 3 & $\begin{array}{l}\text { Pengangkatan bijih } \\
\text { lateric }\end{array}$ & $\begin{array}{l}\text { Emisi yang dihasilkan saat pengangkutan bijih } \\
\text { lateric menuju srockpile }\end{array}$ & Partikulat \\
\hline 4 & $\begin{array}{l}\text { Erosi angin di area } \\
\text { pertambangan }\end{array}$ & $\begin{array}{l}\text { Emisi yang dihasilkan akibat erosi angin di area } \\
\text { yang ditambang }\end{array}$ & Partikulat \\
\hline 5. & Klasifikasi bijih & $\begin{array}{l}\text { Emisi dihasilkan saat bijih diklasifikasikan agar } \\
\text { pengangkutan menjadi lebih mudah }\end{array}$ & Partikulat \\
\hline 6 & Kendaraan berat & $\begin{array}{l}\text { Emisi yang dihasilkan dari kegiatan operasional alat } \\
\text { tambang }\end{array}$ & Partikulat \\
\hline \multicolumn{4}{|c|}{ Emisi Dari Pabrik Pengolahan } \\
\hline 1 & $\begin{array}{l}\text { Pengangkutan dan } \\
\text { bongkar muat bijih di } \\
\text { stockpile }\end{array}$ & Emisi saat bongkar muat bijih lateric di stockpile & Partikulat \\
\hline
\end{tabular}




\begin{tabular}{|c|c|c|c|}
\hline No. & Sumber Emisi & Deskripsi & $\begin{array}{l}\text { Parameter } \\
\text { Emisi }\end{array}$ \\
\hline 2 & $\begin{array}{l}\text { Erosi angin dari } \\
\text { stockpile }\end{array}$ & $\begin{array}{l}\text { Emisi partikel yang terangkat akibat tiupan angin di } \\
\text { stockpile }\end{array}$ & Partikulat \\
\hline 3 & Pemindahan bijih & $\begin{array}{l}\text { Emisi saat pemindahan bijih lateric dengan } \\
\text { menggunakan conveyor }\end{array}$ & Partikulat \\
\hline 4 & Crushing dan Grinding & $\begin{array}{l}\text { Emisi ketika bijih saprolite dan limonite } \\
\text { dihancurkan }\end{array}$ & Partikulat \\
\hline 5 & Atmospheric Leaching & $\begin{array}{l}\text { Emisi dari cerobong yang dilengkapi alat } \\
\text { pengendali emisi }\end{array}$ & $\mathrm{SO}_{2}$ \\
\hline 6 & Pengeringan Nikel & Emisi dari pengeringan cake nikel & Partikulat \\
\hline 7 & Netralisasi sekunder & $\begin{array}{l}\text { Emisi dari cerobong yang dilengkapi alat } \\
\text { pengendali emisi }\end{array}$ & $\mathrm{SO}_{2}$ \\
\hline 8 & Cobalt Recovery & $\begin{array}{l}\text { Emisi dari cerobong yang dilengkapi alat } \\
\text { pengendali emisi }\end{array}$ & $\mathrm{H}_{2} \mathrm{~S}$ \\
\hline \multicolumn{4}{|c|}{ Emisi Dari Pengangkutan Dan Pemrosesan Batu Kapur } \\
\hline 1 & Klasifikasi batu kapur & Emisi dari crushing dan screening & Partikulat \\
\hline 2 & Pemindahan limestone & $\begin{array}{l}\text { Emisi saat pemindahan limestone dengan } \\
\text { menggunakan conveyer dan truk }\end{array}$ & Partikulat \\
\hline 3 & Lime kiln & Emisi yang dihasilkan saat pembakaran lime & $\begin{array}{l}\text { Partikulat, } \\
\mathrm{SO}_{2}, \mathrm{NOx}\end{array}$ \\
\hline \multicolumn{4}{|c|}{ Emisi dari Pabrik Asam Sulfat } \\
\hline 1 & $\begin{array}{l}\text { Konversi } \mathrm{SO}_{2} \text { menjadi } \\
\mathrm{SO}_{3}\end{array}$ & Emisi dari cerobong & $\begin{array}{c}\mathrm{SO}_{2} \\
\mathrm{SO}_{3}+\mathrm{H}_{2} \mathrm{SO}_{4}\end{array}$ \\
\hline
\end{tabular}

\section{Laju Emisi Dari Pertambangan Bijih}

Pertambangan bijih dilakukan di dua area utama, yaitu Bukit limber dan Coastal. Pencemar utama yang dihasilkan dari kegiatan operasional pertambangan bijih adalah partikulat sebagai emisi fugitive. Area pertambangan bijih yang dikaji meliputi lokasi penambangan bijih dan temporary stockpile. Sumber emisi dari penambangan bijih meliputi kegiatan-kegiatan penambangan. Sementara itu, sumber emisi dari temporary stockpile merupakan kegiatan yang terjadi di lokasi tempat penyimpanan sementara overburden dan tanah puncuk sebelum digunakan untuk pembentukan kembali permukaan tanah di area bekas penambangan. Dengan menggunakan Persamaan 1, laju emisi dari pertambangan bijih di Bukit limber dan Coastal dihitung dan hasilnya dapat dilihat pada Gambar 2. 
Kajian Emisi Partikulat Dan Gas Dari Suatu Pertambangan Nikel Di Halmahera Tengah

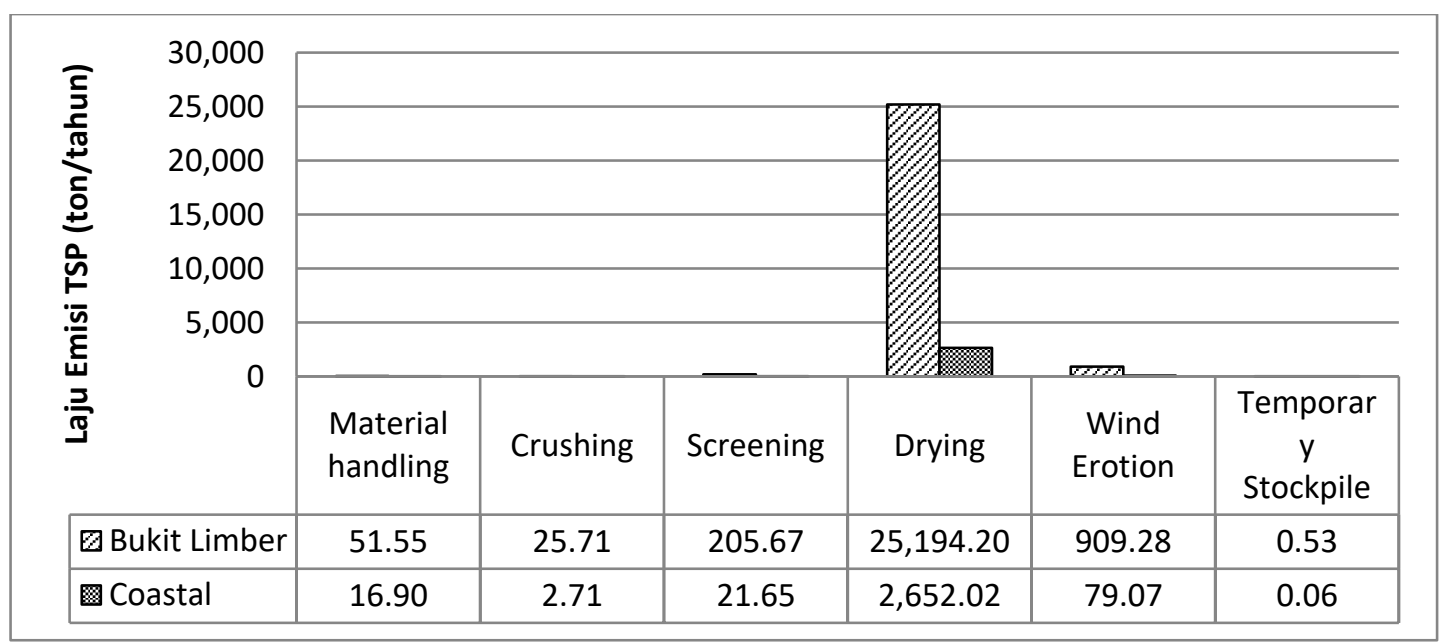

Gambar 2. Laju Emisi TSP dari Pertambangan Bijih

Berdasarkan Gambar 2 diketahui bahwa total laju emisi TSP dari kegiatan operasional tambang bijih adalah 29.159,34 ton/tahun. Emisi partikulat dihasilkan dari beberapa kegiatan, yaitu pengeringan bijih $(95,50 \%)$, erosi angin terhadap area pertambangan (3,39\%), screening $(0,78 \%)$, material handling $(0,23 \%)$, crushing $(0,10 \%)$, dan temporary stockpile $(0,002 \%)$. Jika dibandingkan antara kedua area utama penambangan, dapat dilihat bahwa laju emisi di deposit Bukit limber lebih besar dibandingkan deposit Coastal. Hal ini dikarenakan jumlah bijih yang ditambang di Bukit limber lebih banyak, menyebabkan tingkat aktivitas pertambangan bijih di Bukit limber lebih tinggi.

\section{Laju Emisi Dari Pengolahan Bijih}

Lokasi ini merupakan tempat pengolahan bijih yang ditambang dari Bukit limber dan Coastal. Sumber emisi di lokasi ini berasal dari kegiatan stockpiling dan pabrik pengolahan bijih. Definisi dari kegiatan stockpiling yaitu bijih yang ditambang dari deposit Bukit limber dan Coastal dikumpulkan dan dicampur terlebih dahulu di stockpile yang berlokasi dekat pabrik pemrosesan. Keberadaan stockpile di area pabrik pengolahan menambah potensi emisi partikulat. Sementara itu, sumber emisi dari pabrik pengolahan bijih adalah proses-proses pengolahan bijih. Namun, tidak semua proses pengolahan menghasilkan emisi ke atmosfer. Proses pengolahan yang menghasilkan emisi meliputi crushing, handling, atmospheric leaching, netralisasi sekunder, pengeringan nikel, dan cobalt recovery. Dengan menggunakan Persamaan 1, laju emisi dari stockpiling dan pengolahan bijih dihitung dan hasilnya dapat dilihat pada Gambar 3.

Berdasarkan Gambar 3 diketahui bahwa total laju emisi TSP dari lokasi pengolahan bijih adalah 599,23 ton/tahun. Kegiatan stockpiling berkontribusi terhadap emisi TSP sebesar 72,96\% sedangkan kontribusi pabrik pengolahan bijih sebesar 27,04\%. Sumber emisi TSP di stockpile meliputi wind erotion $(82,37 \%)$, unloading $(15,03 \%)$, dan loading $(2,60 \%)$. Sementara itu, sumber emisi TSP dari pabrik pengolahan bijih yaitu crushing $(81,08 \%)$ dan material handling $(18,92 \%)$. 


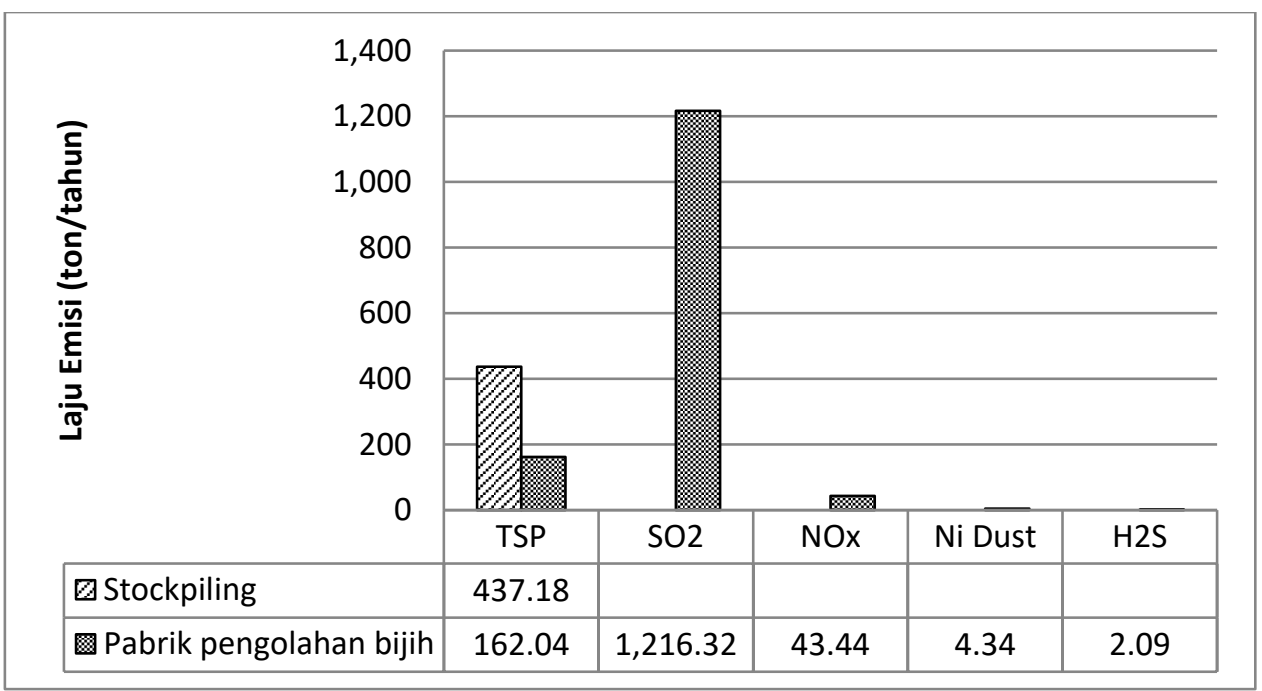

Gambar 3. Laju Emisi TSP dan Gas dari Pengolahan Bijih

Selain mengemisikan partikulat, tempat pengolahan bijih juga mengemisikan gas pencemar yang berasal dari pabrik pengolahan bijih. Berdasarkan Gambar 3, diketahui bahwa emisi terbesar dari pabrik pengolahan bijih adalah $\mathrm{SO}_{2}$. Sumber emisi $\mathrm{SO}_{2}$ meliputi proses netralisasi sekunder $(57,14 \%)$, atmospheric leaching $(21,43 \%)$, dan pengeringan nikel $(21,43 \%)$. Sementara itu, NOx dan debu nikel berasal dari proses pengeringan nikel, sedangkan $\mathrm{H}_{2} \mathrm{~S}$ dihasilkan oleh proses cobalt recovery.

\section{Laju Emisi Dari Pengangkutan dan Pengolahan Batu Kapur}

Pengangkutan dan pengolahan batu kapur dilakukan untuk memenuhi kebutuhan penggunaan batu kapur dalam proses pengolahan bijih. Partikulat adalah pencemar yang dominan dihasilkan selama kegiatan operasional berlangsung. Dengan menggunakan Persamaan 1, laju emisi dari pengangkutan dan pengolahan batu kapur dihitung dan hasil perhitungan tingkat emisi dapat dilihat pada Gambar 4.

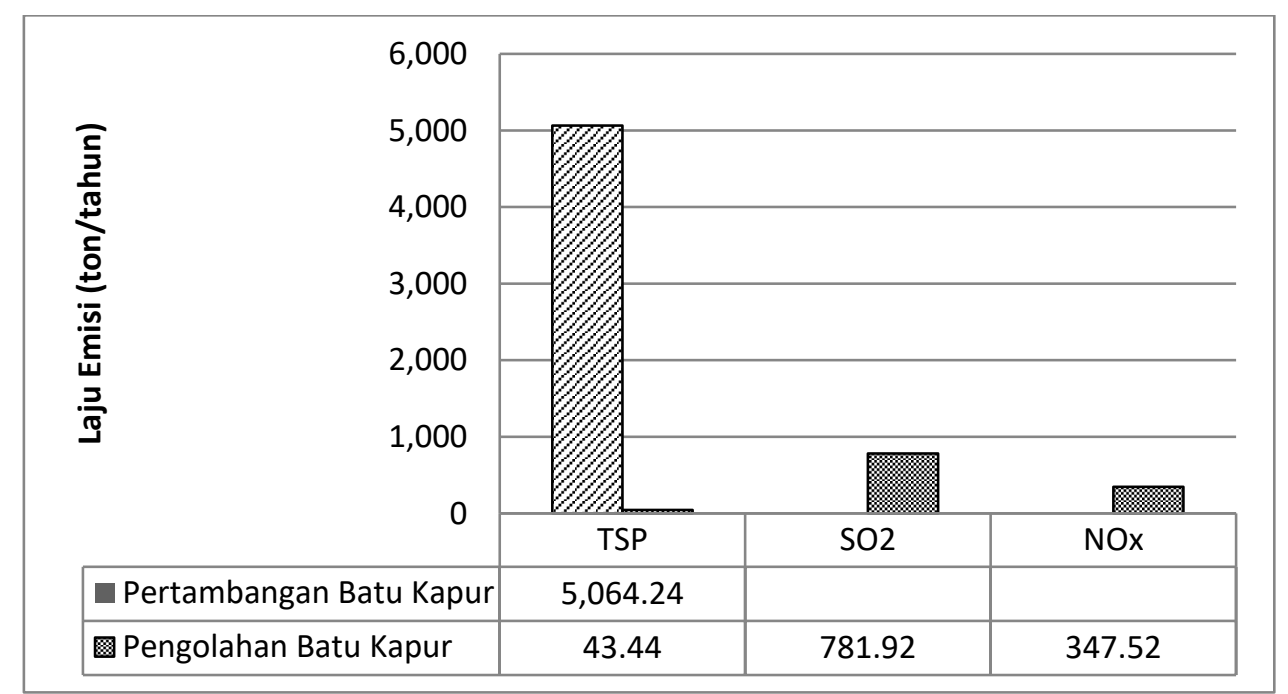

Gambar 4. Laju Emisi TSP dan Gas dari Pengangkutan dan Pengolahan Batu Kapur

Berdasarkan Gambar 4, diketahui bahwa total emisi TSP di area pengangkutan dan pengolahan batu kapur adalah sebesar 5.107,68 ton/tahun. Sumber emisi TSP di area tersebut yaitu pertambangan batu kapur $(99,15 \%)$ dan pengolahan batu kapur $(43,33 \%)$. Sumber emisi partikulat dari pertambangan kapur meliputi screening $(68,76 \%)$, crushing $(30,72 \%)$, dan conveying $(0,52 \%)$. Sementara itu, emisi TSP dari pengolahan kapur berasal dari proses pembakaran kapur. Selain pencemar TSP, proses pembakaran kapur juga mengemisikan gas pencemar $\mathrm{SO}_{2}$ dan $\mathrm{NOx}$. 


\section{Laju Emisi Dari Fasilitas Pendukung}

Fasilitas pendukung yang berpotensi menghasilkan emisi adalah pabrik asam sulfat dan backup boiler. Asam sulfat diproduksi di pabrik tersendiri dengan bahan baku sulfur padat. Salah satu proses pengolahan yang berpotensi menghasilkan emisi ke atmosfer adalah proses konversi $\mathrm{SO}_{2}$ menjadi $\mathrm{SO}_{3}$. Pencemar yang diemisikan adalah $\mathrm{SO}_{2}$ yang tidak berhasil dikonversi karena adanya keterbatasan kemampuan konversi (efisiensi konversi maksimal). Efisiensi konversi dari unit converter ini adalah sebesar $99,7 \%$, sehingga hanya $0,3 \% \mathrm{SO}_{2}$ yang terlepas ke atmosfer. Berdasarkan data yang diperoleh, laju emisi $\mathrm{SO}_{2}$ adalah sebesar $700 \mathrm{~kg} / \mathrm{jam}$. Jadi, emisi $\mathrm{SO}_{2}$ dari pabrik asam sulfat dalam satu tahun sebesar 6.081,6 ton.

Gas yang dilepaskan ke atmosfer dari pabrik asam sulfat tidak hanya $\mathrm{SO}_{2}$ tetapi juga $\mathrm{SO}_{3} \cdot \mathrm{Gas} \mathrm{SO}_{3}$ yang merupakan hasil konversi dari $\mathrm{SO}_{2}$ tidak sepenuhnya aman karena $\mathrm{SO}_{3}$ yang terlepas ke atmosfer kemungkinan mengandung $\mathrm{H}_{2} \mathrm{SO}_{4}$. Berdasarkan data yang diperoleh, laju emisi $\mathrm{SO}_{3}+\mathrm{H}_{2} \mathrm{SO}_{4}$ adalah sebesar $30 \mathrm{~kg} / \mathrm{jam}$. Jadi, jumlah emisi $\mathrm{SO}_{3}+\mathrm{H}_{2} \mathrm{SO}_{4}$ dari pabrik asam sulfat dalam satu tahun adalah sebesar 260,64 ton.

Sementara itu, back up boiler berfungsi untuk menjamin ketersediaan tenaga uap yang cukup selama pabrik asam beroperasi. Sumber energi dari back up boiler adalah bahan bakar minyak industri. Pembakaran minyak industri akan menghasilkan emisi gas berupa $\mathrm{NOx}$ dan $\mathrm{SO}_{2}$. Berdasarkan data yang diperoleh, laju emisi $\mathrm{NOx}$ dan $\mathrm{SO}_{2}$ adalah sebesar $6 \mathrm{~kg} / \mathrm{jam}$ dan $36 \mathrm{~kg} / \mathrm{jam}$. Jadi, jumlah NOx dan $\mathrm{SO}_{2}$ yang dilepaskan backup boiler dalam satu tahun adalah sebesar 52,13 ton dan 312,77 ton.

\section{Laju Emisi Dari Sektor Transportasi}

Sektor transportasi berpotensi berpotensi menghasilkan pencemar partikulat dan gas. Emisi dari sektor transportasi berasal dari kegiatan penambangan bijih, pengangkutan bijih, dan resuspensi jalan yang diakibatkan oleh operasional kendaraan berat. Dengan menggunakan Persamaan 1, jumlah emisi TSP dan NOx dari masing-masing sumber di Bukit Limber dan Coastal dihitung dan hasilnya dapat dilihat pada Gambar 5.

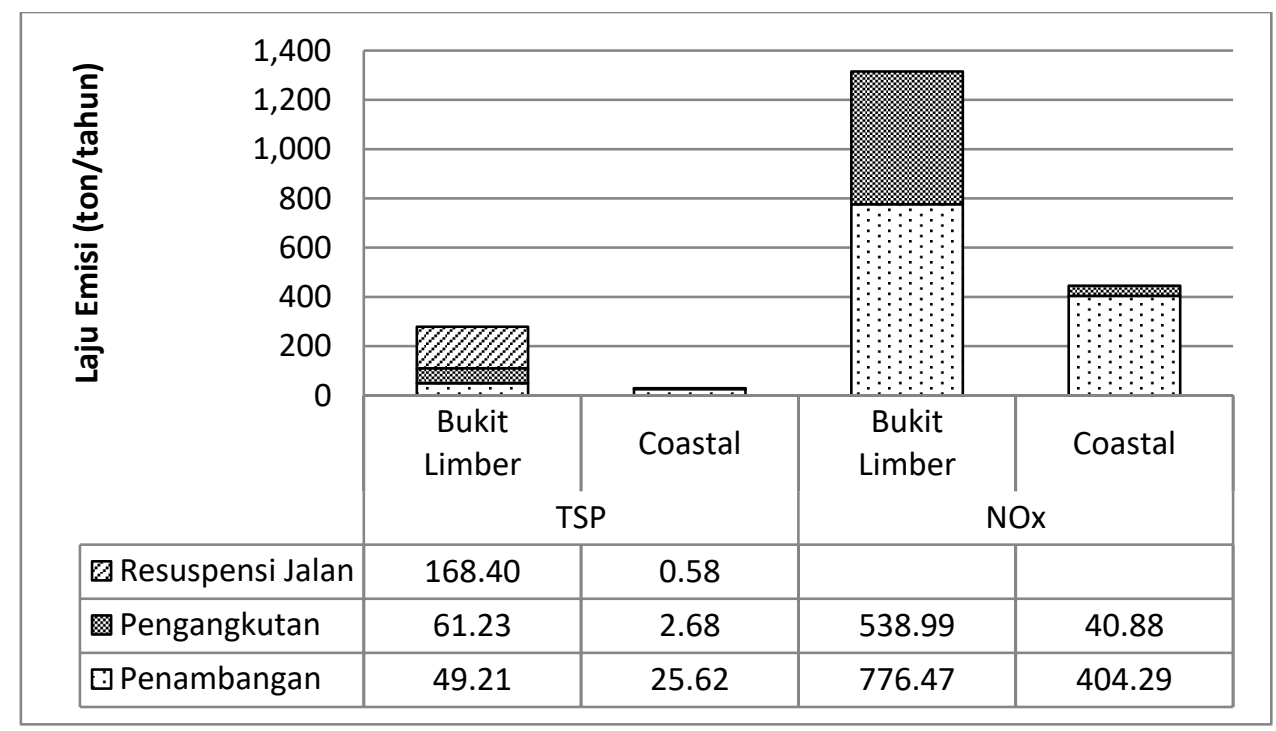

Gambar 5. Laju Emisi TSP dan NOx dari Sektor Transportasi

Berdasarkan Gambar 5, diketahui bahwa total emisi TSP dan NOx dari sektor transportasi berturutturut adalah sebesar 307,72 ton/tahun dan 1.760,63 ton/tahun. Sumber emisi TSP meliputi resuspensi jalan $(54,91 \%)$, penambangan $(24,32 \%)$, dan pengangkutan $(20,77 \%)$. Sementara itu, sumber emisi NOx hanya berasal dari kegiatan penambangan $(67,06 \%)$ dan pengangkutan $(32,94 \%)$. Emisi di Bukit Limber lebih besar dari pada Coastal karena aktivitas pertambangan di Bukit limber lebih tinggi daripada Coastal. Tingginya aktivitas pertambangan diperlihatkan dengan tingginya jarak tempuh kendaraan berat di Bukit Limber. 


\section{Rekapitulasi Tingkat Emisi Di Pertambangan Nikel}

Setelah menghitung tingkat emisi di masing-masing kegiatan pertambangan nikel, maka perlu dilakukan rekapitulasi tingkat emisi untuk mengetahui seberapa besar total emisi yang dihasilkan dari pertambangan nikel. Hasil rekapitulasi laju emisi berdasarkan sumber emisi dapat dilihat pada Gambar 6.

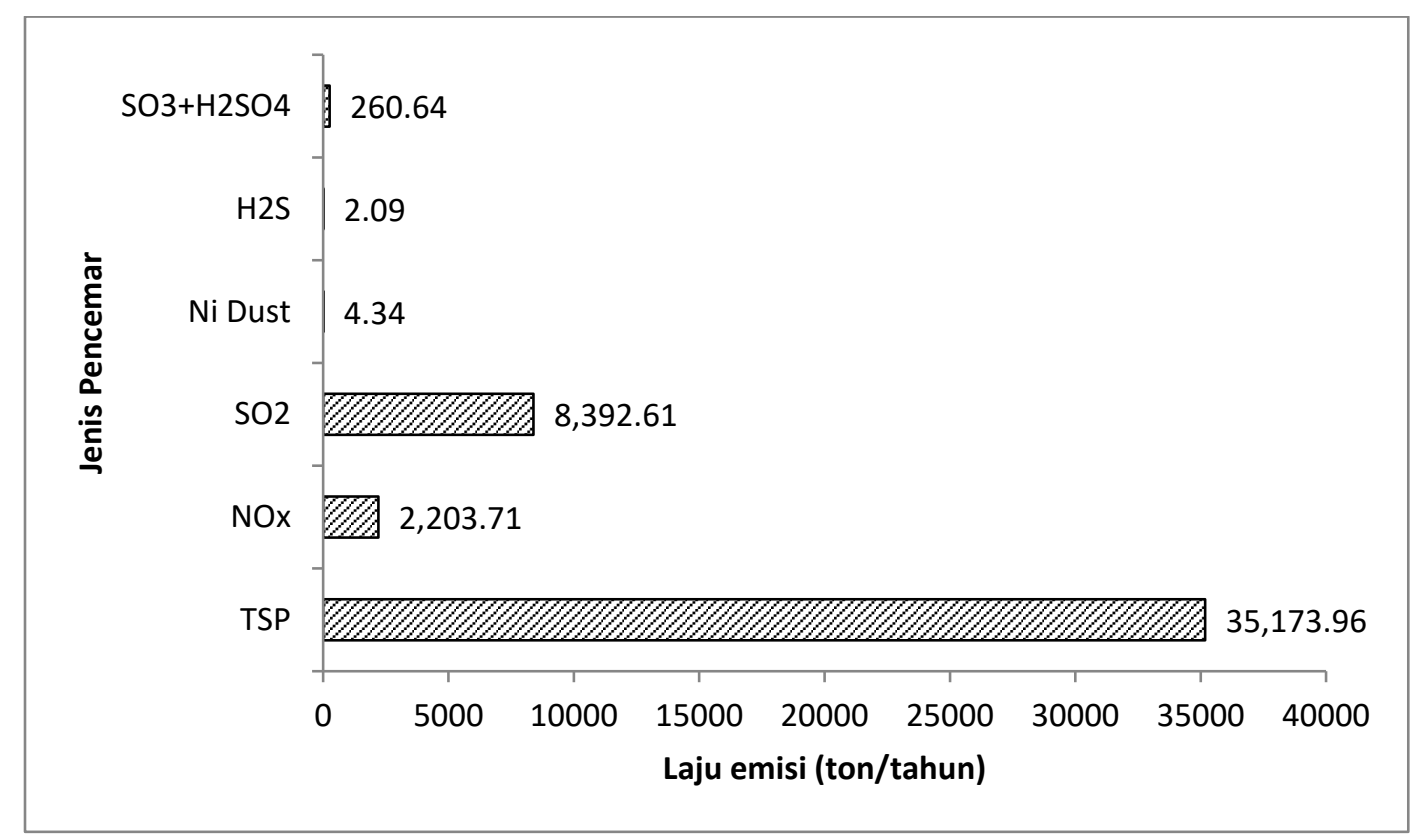

Gambar 6. Rekapitulasi Laju Emisi TSP dan Gas di Pertambangan Nikel

Berdasarkan Gambar 6, jenis pencemar utama yang diemisikan dari seluruh kegiatan tambang nikel adalah partikulat dengan jumlah 35.173,96 ton/tahun. Pencemar lain dengan jumlah yang signifikan adalah $\mathrm{SO}_{2}$ dengan laju emisi 8.392,61 ton/tahun dan NOx dengan laju emisi 2.203,71 ton/tahun. Sementara itu, komposisi sumber emisi untuk pencemar partikel, $\mathrm{SO}_{2}$ dan $\mathrm{NOx}$ dapat dilihat pada Gambar 7 - Gambar 9. Sumber utama emisi partikulat adalah penambangan bijih (Gambar 7) dengan kontribusi sebesar $83 \%$. Sementara itu, sumber emisi utama gas $\mathrm{SO}_{2}$ dan $\mathrm{NOx}$ berturut-turut yaitu pabrik pengolahan asam sulfat (Gambar 8) dengan kontribusi sebesar $72 \%$ dan transportasi bijih (Gambar 9) dengan kontribusi sebesar 80\%.

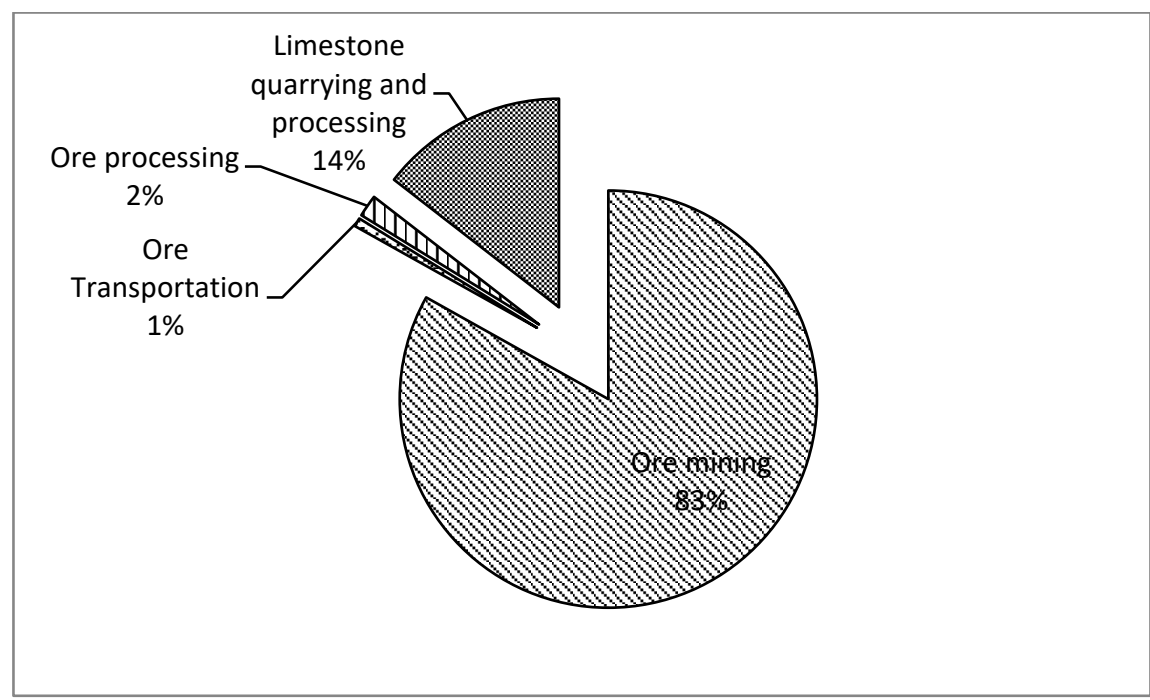

Gambar 7. Komposisi Sumber Emisi TSP 


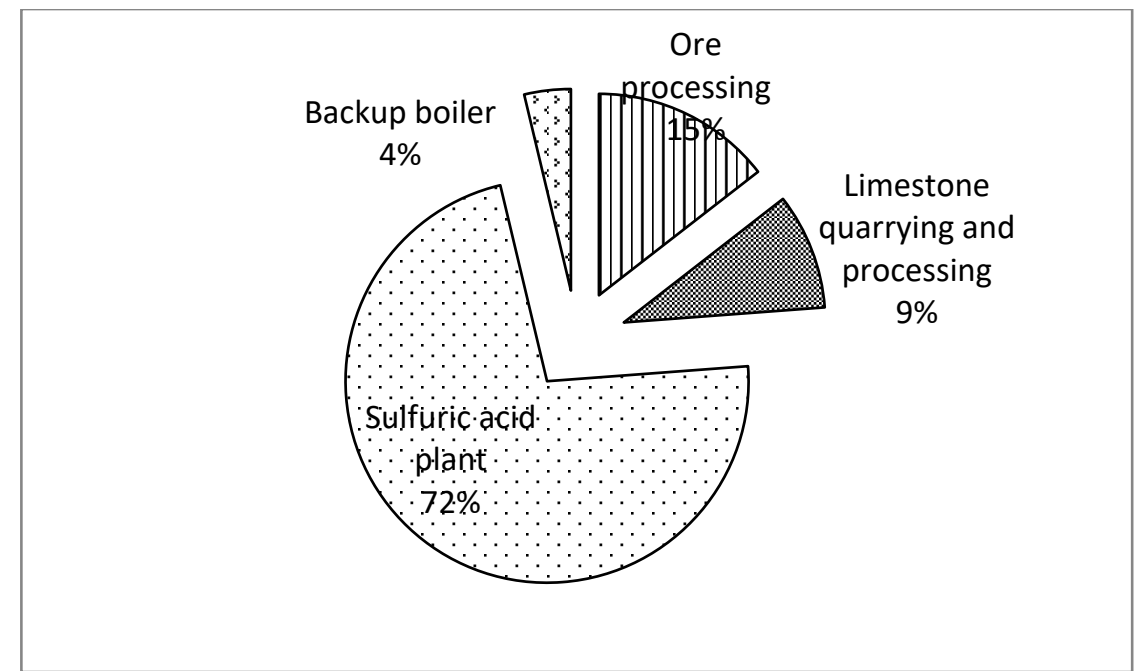

Gambar 8. Komposisi Sumber Emisi $\mathrm{SO}_{2}$

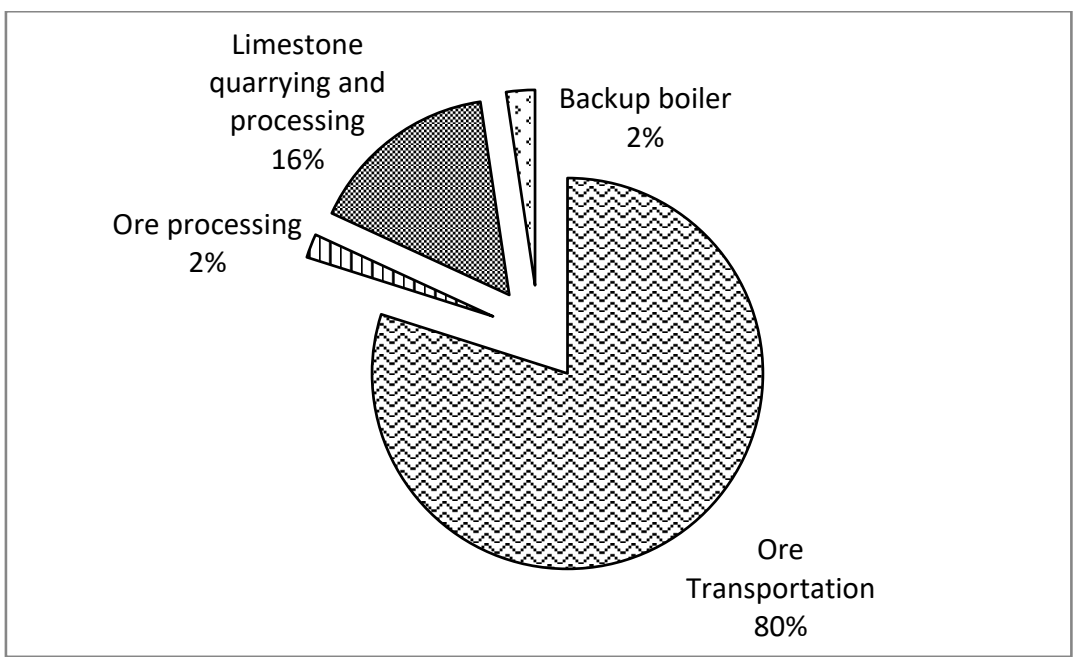

Gambar 9. Komposisi Sumber Emisi NOx

\section{KESIMPULAN}

Pertambangan nikel berpotensi mengeluarkan emisi dari beberapa jenis pencemar, yaitu TSP, NOx, $\mathrm{SO}_{2}, \mathrm{H}_{2} \mathrm{~S}$, debu nikel, dan $\mathrm{SO}_{3}+\mathrm{H}_{2} \mathrm{SO}_{4}$. Pencemar yang paling banyak diemisikan di pertambangan nikel adalah TSP dengan laju emisi sebesar 35.173,96 ton/tahun. Sumber emisi TSP meliputi pertambangan bijih (83\%), penggalian dan pengolahan batu kapur (14\%), pengolahan bijih (2\%), dan transportasi bijih (1\%). Pencemar gas yang paling banyak diemisikan di pertambangan nikel adalah $\mathrm{SO}_{2}$ dan NOx, dengan laju emisi $\mathrm{SO}_{2}$ dan NOx berturut-turut adalah sebesar 8.392,61 ton/tahun dan 2.203,71 ton/tahun. Sumber emisi $\mathrm{SO}_{2}$ meliputi pabrik asam (72\%), pengolahan bijih (15\%), pengolahan batu kapur (9\%), dan backup boiler (4\%). Sementara itu, sumber emisi NOx meliputi transportasi bijih (80\%) pengolahan batu kapur (16\%), pengolahan bijih (2\%) dan Backup boiler (2\%). 


\section{DAFTAR PUSTAKA}

[1] Hoatson, D.M., Jaireth, S., Jaques, A.L. (2006). Nickel sulfide deposits in Australia: characteristics, resources and potential. Bijih Geology Reviews 29, 177-241

[2] Elias, M. (2002). Nickel laterite deposits—geological overview, resources and exploitation.In: Cooke, D.R., Pongratz, J. (Eds.), Giant bijih deposits: charatceristics, genesis and exploration. Centre for Bijih Deposit Research, University of Tasmania, Hobart,TAS, pp. 205-220.

[3] USGS, var.-a. Minerals commodity summaries. US Geological Survey (USGS), Years 1996 to 2009, Reston, Virginia, USA.

[4] Mudd, G.M. (2010). Global trends and environmental issues in nickel mining: Sulfides versus laterites, Bijih Geol. Rev.(2010).

[5] Bluher (2008). Tugas Akhir : Kajian Emisi Partikulat yang Berasal dari Aktivitas Pertambangan Batu Bara. Teknik Lingkungan ITB.

[6] US EPA. (1995). AP 42, Fifth Edition Compilation of Air Pollutant Emission Factors, Volume 1: Stationary Point and Area Sources, New York, USA. 